Winter 2016

\title{
The Long Road Toward a More Perfect Union: Majority Rule and Minority Rights at the Constitutional Convention
}

John Patrick Coby

Smith College, pcoby@smith.edu

Follow this and additional works at: https://scholarworks.smith.edu/gov_facpubs

Part of the American Politics Commons

\section{Recommended Citation}

Coby, John Patrick, "The Long Road Toward a More Perfect Union: Majority Rule and Minority Rights at the Constitutional Convention" (2016). Government: Faculty Publications, Smith College, Northampton, MA.

https://scholarworks.smith.edu/gov_facpubs/1 


\title{
The Long Road toward a More Perfect Union: Majority Rule and Minority Rights at the Constitutional Convention
}

\author{
JOHN PATRICK COBY
}

\begin{abstract}
On the eve of the Constitutional Convention, James Madison developed a new theory of republicanism, one that would allow union on a scale previously thought impossible. The extended republic, buttressed by constitutional safeguards republican in nature, would, he argued, protect the rights of minorities without compromising the majority's right to rule. But Convention delegates, unimpressed with Madison's new theory, gravitated toward constitutional safeguards more mixed-regime in nature and so produced a constitution incompletely republican. This article examines the three minority interests that most occupied the delegates' attention: small states, all states, and southern states; further, it employs three criteria for determining the presence of republican or mixedregime protections: strength of constitutional barrier, cohesion of defenders, and duration of defense. The article's conclusion reflects on the consequences of a constitution partly republican and partly mixed-regime.
\end{abstract}

James Madison in Federalist 10 provides a searching analysis of the problem besetting popular governments, past and present. According to Madison, a known principle of law - that parties to a cause not at the same time be judges of that cause-is violated in the case of democratic lawmaking, since legislators are little different from advocates for, and parties to, the causes they determine; as such, they are liable to corruption by passion and interest, no less than are individuals when placed in like circumstances. Popular governments empower the majority, and the majority operates as an unjust faction when it

John Patrick Coby is professor of government at Smith College, 1 Chapin Way, Northampton, MA 01063 (pcoby@smith.edu).

I wish to express my appreciation to the journal's reviewers, whose helpful comments guided my revisions.

American Political Thought: A Journal of Ideas, Institutions, and Culture, vol. 5 (Winter 2016).

2161-1580/2016/0501-0002 $\$ 10.00$. @ 2016 by The Jack Miller Center. All rights reserved. 
enacts laws in disregard of the rights of minorities or the good of the community. Madison's famous prophylactic for the tyranny of the majority is an enlargement of the size of the state, called the "sphere," coupled with constitutional protections called "auxiliary precautions." This combination of correctives is thought to be consistent with the sovereignty of the people and thus to qualify as "a republican remedy for the diseases most incident to republican government."

Although Madison tries to persuade his colleagues at the Constitutional Convention of the curative effects of the extended sphere, he fails, it seems, even to hold their attention. Not believing that the country is tending toward a "more perfect union" of similar peoples and regions, the delegates, or a sizable portion of them, favor instead minority protections proper to a mixed regime over those proper to a republic; accordingly, the constitution they write is a composite of republican and mixed-regime elements, notwithstanding Madison's description of it in Federalist 14 as an unmixed, extensive republic. ${ }^{1}$

Later in the Federalist Papers, in no. 51, Madison lays out the twin tasks facing political science when framing a republican form of government. ${ }^{2}$ The

1. Three authors who examine the Constitution in terms of a mixed regime are Eidelberg (1968), Diamond (1992), and Adair (1998). Eidelberg argues, against Diamond, that the government created by the Constitution is a mixed regime (Eidelberg 1968, 3). Diamond argues, against Beard (1913) and others, that the government created is a qualified democracy, reflecting the influence of ideas and experience, rather than an unqualified oligarchy, conforming to the laws of economic determinism (Diamond 1992, 19-27). Adair follows John Adams in describing the government as "quasi-mixed" (Adair 1998, 175). This article fits midway between Eidelberg and Diamond; it thus aligns with Adair, though it reaches its conclusion by a different route, one that looks beyond the monarchic and aristocratic features of the Constitution. It also connects with a more recent discussion of the impact of Madison's extended-republic theory on the Convention debates. Contributors for the maximalist position (with Diamond at the lead) are Brant (1950, 43), Rossiter (1966, 247), Rakove (1987, 427, 434, 456), Diamond (1992, 98-107), and Miller (1992, 22-33, 53-60). Contributors for the minimalist position (with Kramer at the lead) are Wolfe (1977, 104), Schultz (1980, 222), Zuckert (1986, 191-92), Hutson (1987, 420-22), Nelson (1987, 462), and Kramer (1999, 615, 637-39, 657-64). Banning (1995, 138-39) occupies a middle ground with his thesis that Madison adjusted his thinking as the Convention progressed. This article sides with those who would lessen Madison's impact. Gibson (2008b, 63-87) provides a literature review. Related to the above is a body of scholarship emphasizing the contribution of small-state delegates to the Convention and the successes they scored against Madison's nationalism. Contributors are Slonin (2000, 1-19) and Robertson (2005, 22543). This article builds on that scholarship by explaining the theory that underwrites smallstate, confederal successes.

2. "Republic," in this article, identifies a form of popular government in which the exercise of majority rule is qualified by respect for minority rights, or a form of government in which the principle of equality is compounded with the principle of liberty. Madison defines a republic more broadly in Federalist 14 and Federalist 39, calling it in no. 14 an indirect, representative democracy, necessary when communities are large, and in no. 39 a government whose powers derive from the people and whose officers, drawn from the whole of society, 
first is to invest government with powers sufficient to control the governed; the second is to prevent government from abusing the powers it has been given. One might say that the act of founding a republic consists of a Hobbesian moment succeeded by a Lockean moment. ${ }^{3}$

A third task is appended by Madison, namely, to guard one part of society from the injustice of another part, or to protect the rights and interests of minorities from oppression by the majority. Failure to address this third problem will most likely result in a failure to address the second as well-meaning that no Lockean moment in which government is limited and placed under law will follow the Hobbesian moment in which government is made powerful and perhaps absolute. The reason is that factions in society, like individuals in a state of nature, will find unacceptable the degree of violence that obtains when factions are free to do as they please, with even the dominant faction applying for protection and demanding a government strong enough to supply it. Either majority tyranny is checked in a manner consistent with limited government, or society's factions will seek succor in a government subject to few, if any, constraints.

Madison goes on to suggest that two methods avail of averting this recourse to Hobbesian absolutism. The first is to create "a will in the community independent of the majority." This somewhat oblique phrasing is a reference to the obstructing power routinely accorded a king in a constitutional monarchy (Carey 1995, 40; Zuckert 2013, 106). The monarchy represents a separate estate with a will of its own, independent of the majority, and the bolstering of that will by means of a veto and other extra-democratic prerogatives is cited as the first method of checking the majority, short of resorting to absolute rule.

The second-and the one for which Madison is best known-is to fracture the majority by extending the country's size. Because an extended republic contains a multitude of interests, a majority party will perforce consist of a

serve for limited terms. Madison's broader definitions describe a regime not yet cured of the disease of popular government, namely, majority tyranny. Since it is Madison's overarching purpose to supply such a cure, a regime that is cured is more precisely a Madisonian republic, notwithstanding the broader definitions in nos. 14 and 39, which Madison offers in response to the errant opinions of others. See Diamond et al. $(1966,70-74)$ and Eidelberg $(1968,72-$ 74).

3. Corresponding to these "Hobbesian" and "Lockean" moments, so called, is the distinction made at the Convention between the powers and structures of political offices and the proper ordering of the two: whether, for example, to begin by investing the executive with "Hobbesian" powers necessary to carrying out the duties of the office (e.g., veto, appointment, commander in chief, treaties, pardon), or to begin by devising "Lockean" structures necessary to protecting liberty and the independence of other branches (e.g., number, election, term, reeligibility, impeachment). Generally, the Convention proceeded backward, ignoring Madison's advice to put powers first (June 1). See Davis (1978, 87-88). 
temporary and fragile coalition of minor parties and "can seldom take place on any other principles than those of justice and the general good." And because a majority so constituted will expose a minority to substantially less danger, there will "be less pretext, also, to provide for the security of the former, by introducing into the government a will not dependent on the latter, or, in other words, a will independent of the society itself." All power can safely emanate from the people if the people do not divide into two, fixed parties, one of which alone can capture government and make laws to suit its own purposes.

\section{SMALL REPUBLICS AND EXTENDED REPUBLICS}

At the Constitutional Convention of 1787, Madison argues at length-though mostly only once-for defending the rights of minorities by the method of fracturing majorities. The large republic, he contends, will do much of the work of protecting the few from the predations of the many, thus sparing the Constitution from having to incorporate elements inconsistent with republican principles. Size alone is not enough, but size shapes the character of constitutional safeguards that come later.

June 6 is the day when Madison rolls out his theory of the extended republic, a version of which he wrote up just prior to the Convention in a memorandum titled "Vices of the Political System of the United States." The topic before the Convention this day is the election of the lower house, whether by the people, as stipulated in the Virginia Plan and as provisionally approved by the Convention on May 31, or by the state legislatures, as now proposed by the South Carolina delegates, Charles Pinckney and John Rutledge.

Madison directs his remarks to Roger Sherman of Connecticut, who, in pressing the case for election by state legislatures, claims that the responsibilities of the national government are few in number: defense against foreign invasions and domestic uprisings, treaties, commerce, and taxes. His reason for constricting the national government to these few general items is that criminal and civil matters rest properly with the states. That is so, Sherman avers, because states, if small, can better provide for the happiness of the people.

Sherman is referencing a theory of republicanism whose modern iteration originates with Montesquieu. The theory holds that republican government is appropriate to small territories, since in extensive territories men of grand fortunes entertain ambitions that exceed the bounds of their states; moreover, in large states, including large republics, private interest takes precedence over the public good, whereas in small republics the public good is readily comprehended by the citizenry and directly beneficial to them. Montesquieu further explains that small republics can protect themselves from the aggression of 
monarchies and empires by joining together in defensive alliances. Alliances guard against dangers without, while the member states attend to the internal happiness of their separate populations (Montesquieu, Spirit of the Laws 8.16, 9.1).

Madison rushes to contest the claim that small republics deliver justice and safeguard liberty more reliably than do large republics, for if true, or accepted as true, the Convention is effectively restricted to amending the Articles of Confederation, a charter of union based on the Montesquieuian model. But America's experience, in Madison's judgment, has proven the opposite to be true, since the states-and the small ones especially-have trampled on the rights of individuals. Included then among the powers appropriate for the national government to assume are "the security of private rights and the steady dispensation of Justice" (June 6, Farrand 1966-87, 1:134) ${ }^{4}$ - the very police powers that Sherman maintains are properly the province of the states. Madison is confident that the national government can better carry out these moral responsibilities because it will represent the diversified interests of a large society. If people cannot be trusted to set aside their own interests for the greater good or for the rights of others (and Madison believes that they cannot), and if people collected into parties are more selfish still, as well as less constrained by reason, reputation, and religion (and Madison believes that they are), then "the only defense against the inconveniences of democracy consistent with the democratic form of Government" is the multiplication of interests that arises automatically in "civilized Societies" large in size. Rich and poor will not face each other as inveterate class enemies if each is subdivided by types of wealth, by places of residence, by political attachments, and by religious sect. On the other hand, let there be two fixed and separated communities, as generally occurs in a compact space, and the inevitable result will be that the stronger of the two will oppress the weaker of the two (Aristotle, Politics 4.11.12-13; Eidelberg 1968, 75-76; Diamond 1992, 33). The antidote, once again, is the enlargement of the sphere and the consequent diversification of interests, for these will prevent a majority of one description (e.g., northerners) from uniting around a common, but selfish, policy (e.g., tariffs to promote northern shipping). Fully elaborated, the theory explains the benefits of size in checking concerted action by a factious majority and in securing election to Congress of quality representatives. With the negative included (i.e., a national veto over

4. Quotations from the Convention debates are from Farrand (1966-87). The first two of Farrand's four volumes contain the notes taken by Convention delegates, excluding those taken by John Lansing (in vol. 4). Misspellings of proper names are corrected; otherwise, original spellings are retained. Original punctuation is also retained, except in cases where it interferes with comprehension. Full words replace abbreviations. 
state laws), most of the remedy is in place for curing the problem of majority tyranny-a remedy, moreover, that is legitimately republican for not relying on "a will in the community independent of the majority" (Federalist 51 ). ${ }^{5}$

\section{REPUBLICAN PROTECTIONS AND MIXED-REGIME PROTECTIONS}

As mentioned, the extended republic needs constitutional safeguards as backup if the rights of minorities are to be made secure. Madison in Federalist 51 calls these safeguards "auxiliary precautions." Alexander Hamilton in Federalist 9 attributes them to a new science of politics, or, to quote him exactly, to a "science of politics" that "has received great improvement." They are auxiliary to a "dependence on the people" (i.e., elections), meant to control the government, and to a "federal republic" (i.e., the extended sphere "broken into so many parts, interests, and classes of citizens"), meant to control the governed (no. 51); further-as they include such innovations as separation of powers, legislative checks and balances, independent judges, and lawmaking by elected representatives in lieu of the people assembled (no. 9) -they provide a point of contact with the mixed regime, the product of an old science of politics.

The old science of politics-as old as the ancients ${ }^{7}$ - depends on the mixed regime to solve the problem of majority tyranny (and all other forms of tyranny). The mixed regime unites elements of the three unitary regimes-mon-

5. Zuckert astutely analyzes the interlocking components of Madison's political science (see Zuckert 1987, 145-49; Zuckert 2003, 158-59, 163-65). Cf. Zvesper (1984, 244-48). Sheehan $(2009,85-106)$ adds public opinion to the mix.

6. Although Madison ties auxiliary precautions (i.e., separation of powers, defended by personal ambition; bicameralism, meant to weaken the legislative branch; and federalism, called "compound republic") to the control of the government, the control of the governed, the majority, is also assisted by them, since the majority acts tyrannically, not by mob violence primarily, but by lawmaking done by government won by election. Madison, in fact, acknowledges the point in a letter to Jefferson (October 17, 1788): "Wherever the real power in a Government lies, there is the danger of oppression. In our Government, the real power lies in the majority of the Community, and the invasion of private rights is chiefly to be apprehended, not from acts of Government contrary to the sense of its constituents, but from acts in which the Government is the mere instrument of the major number of the constituents" (Madison 1975, 9:298). George Carey draws a hard distinction between the control of the government through separation of powers and the control of the governed through the extended sphere (Carey 1995, 58-64). Carey does acknowledge, however, that one purpose of bicameralism is to serve the extended sphere as an "auxiliary precaution" (72). Indeed, the entire apparatus of auxiliary precautions serves the double purpose of guarding against governmental tyranny and guarding against majority tyranny.

7. Plato, Laws 691d-693e; Aristotle, Politics 4.7-9; Polybius, Histories 6.3-10; Cicero, Republic 1.69; also Machiavelli, Discourses on Livy 1.2-6. See Wood (1969, 197-202). 
archy (rule by one, commonly a king), oligarchy/aristocracy (rule by the wealthy few, who may present themselves as the best), and democracy (rule by the people, the demos, who are the many)-and distributes sovereignty among them, rather than locating it all in one place. A monarch exercises executive power (perhaps also judicial power), while legislative power (perhaps with the executive's involvement) is split between representatives of the community's usually two social orders-whether called oligarchs and democrats, patricians and plebeians, ottimati and popolo, or nobles and commoners. In the British case, and as pertains to Parliament, each order possesses a separate will, and each protects its interest by means of an absolute veto. Lawmaking, when it occurs, requires the consent of both nobles and commoners, along with the consent of the king, taken as a social order in his own right. If either the king or the nobles withhold their consent, the commoners are prevented from acting. Sovereignty does not reside with them; it is a compound built of three distinct parts (Blackstone 1979, 149-51, 155).

The difference between the old and the new science of politics comes down to this: the old, working through the medium of the mixed regime, fortifies the minority by investing it with defensive powers, whereas the new, relying on auxiliary precautions and the extended sphere, weakens and moderates the majority by disrupting its exercise of offensive powers.

The reason for choosing the mixed-regime mode of protecting minorities is the perception that society is not a natural whole, composed of one population, more or less all the same, but is a union of distinct communities artificially brought together (Diamond 1992, 60). Besides the nearly ubiquitous distinction between rich and poor (which may or may not be regarded as essential), essential divisions are those produced by birth, race, ethnicity, geography, religion, language, conquest, colonization, or mere length of residence (gender belongs to its own category because of sexual love, procreation, and the family unit). ${ }^{8}$ Whole bodies of people are the represented parties, since whole bodies are strong enough to bargain on their own behalf. Fair and equal treatment is not expected for individuals when subject to the power of those outside their group. And when the group in question is a state, and the state is joined with others in a confederation of states, the confederation's laws do not ordinarily reach the individual, since it is doubted that the individual's welfare is the object of these laws.

8. Social divisions are classified as essential if they are not easily changed by the parties affected. Two of the delegates, Gouverneur Morris of Pennsylvania and Sherman of Connecticut, dispute the essential character of geography on grounds that the migration of offspring will in time soften the regional loyalties of family members ( July 5, Farrand 1966-87, 2:531; July $14,2: 3$ ). Wealth is essential where it is fixed by law. 
In a republic aspiring to be a more perfect union, sovereignty is whole in the people. Accordingly, the protections of a republic operate differently. In the first place, they are formally divorced from social class or other permanent interests. ${ }^{9}$ The wealthy, the well-born, the descendants of first inhabitants, and so on, have not a legislative chamber of their own, a castle behind whose walls they beat back the assaults of the multitude. Second, these precautions check lawmaking only temporarily and for the purpose of enhancing the wisdom of a measure and broadening its support, whereas the checks applied by mixed regimes typically result in deadlock, broken only when necessity and peril compel positive action (Polybius, Histories 6.18; Montesquieu, Spirit of the Laws 11.6; Diamond 1978, 63-67; Coby 1999, 29-30). As President Washington reputedly explained to Thomas Jefferson, newly returned from France and curious about the Constitution's bicameral legislature, the Senate is the saucer into which legislation, like coffee, is poured to cool. ${ }^{10} \mathrm{Re}$ publican precautions still derogate from popular rule, but they do not deny it or prevent it absolutely, since all branches trace their authority back to the people, who are sovereign. No will exists in society that is not ultimately the will of the people. In a mixed regime, by contrast-and as defined by Madisonsociety contains, and government incorporates, a "will independent of the society itself" (Federalist 51).

An apt metaphor for constitutional protections is the science of water management, or hydro engineering (a metaphor that one of the delegates actually employs). The flow of water can be channeled to control its direction and speed. Consider this a "republican" precaution aimed at preventing erosion and floods (i.e., precipitous legislation). Or the flow can be blocked to hold back the water and keep it in place. Consider this a "mixed-regime" precaution aimed at creating a lake (the people) on one side of the dam and leaving dry land on the other (the nobles). ${ }^{11}$ The image of a large body of water pressing relentlessly against its confines communicates the pertinent lesson that mixed

9. In the absence of permanent social orders requiring independent representation, power may still be divided to guard against its abuse and to recognize and exploit its functional differences. From these two objectives arise the doctrine of separated powers (Locke, Second Treatise, secs. 143-44). Gwyn (1965, 64-65, 127-28) identifies five purposes served by the separation of powers, although four of them relate to the abuse of power. See also Wills (1978, 97-136) and Mansfield (1991, 115-27).

10. This story is perhaps apocryphal since its first known recording is in an 1884 issue of Harper's New Monthly Magazine.

11. Greg Weiner, developing the thesis that Madison's republicanism relied on time to calm passions and return reason to its rightful position of command, ascribes to Madison the belief that the "chief purpose" of institutions, rules, and compacts "was to channel rather than dam the energies of popular majorities" $(2012,2)$. Republics channel; mixed regimes dam. 
regimes, designed to protect the identities of distinct populations, give way in time to republics, dedicated to treating individuals as equals under the law. If the goal is a more perfect union, epitomized by the phrase e pluribus unum, then the mixed regime is, and ought to be, a transitional arrangement.

Difficulties do attend the business of differentiating precautions labeled "republican" from precautions labeled "mixed-regime." Likely these precautions exist on a continuum rather than in discrete compartments, and historical practice is an added and complicating factor. Nevertheless, three features provide some guidance. One is the strength of the barrier erected. Short of a separate government, a separate legislative chamber within a single government is the strongest barrier of all and is the main institutional marker of a mixed regime. ${ }^{12}$ It trumps the constitutional ban, which trumps the executive veto, which trumps the supermajority, which trumps equal voting by unequal entities, and so on. ${ }^{13}$ Attenuated representation and indirect elections are other strategies, though they may cross the line dividing defensive precautions from offensive powers and thus slide the regime toward oligarchy/aristocracy. A second feature is the cohesion of the party manning the barrier. An economic

12. John Adams, the country's leading authority on mixed regimes, recommends in his $A$ Defence of the Constitutions of Government of the United States that the wealthy few, in order to safeguard both their own interest and the independence of the people's representatives, be "ostracized" in a separate chamber of the legislature (Adams 1850-56, 4:290-91, 44445; 5:185-87); see also Rush (1947, 57-64), as well as Gouverneur Morris at the Convention (July 2, Farrand 1966-87, 1:512-13). Adams is not at the Convention, but out of the country serving as ambassador to Great Britain and writing his three-volume Defence. Denied the benefit of Madison's new-science-of-politics thinking, Adams continues to express the old-science-of-politics thinking that minorities need mixed-regime precautions to protect themselves, and that majorities need them too lest they be bullied and beaten by their social superiors (Wood 1969, 567-92). The first volume of the Defence was published in England in January 1787; an American edition was available in Philadelphia by the spring. The extent to which Adams's Defence, or Adams's Thoughts on Government written 11 years earlier, influenced delegates to the Convention is unclear. Luther Martin cites Adams regarding the topic of confederal congresses (June 27, 1:439), but otherwise Adams is not mentioned in the debates. Madison complains of the Defence in a letter written to Jefferson on June 6,1787, the date of Madison's extended-republic speech (Madison 1977, 10:29).

13. A separate legislative chamber has (or will likely have) an absolute veto over the legislation of the other chamber; without the other's consent, this veto cannot be surmounted. A constitutional ban requires a constitutional amendment to remove it, but an amendment does not (or may not) require the consent of all of those opposed; hence, it is a step down from legislative vetoes in a bicameral body. An executive veto, unless absolute, can be overridden, but generally only by supermajorities in the legislature. Likely this veto is stronger than supermajorities on their own, which institute a two-step lawmaking process (approval of one house and then of the other), whereas the veto institutes a five-step process (sequential approvals, veto, sequential overrides), with supermajorities as the final hurdles. Equal voting by unequal entities (e.g., states of varying sizes casting the same vote) is no surety against majority rule, as legislative alignments may from time to time put the interests of lesser entities in jeopardy. 
interest group is weak and amorphous compared with a racial minority or a parcel of territory boasting its own sovereign government. The former is subject to the fragmentation caused by Madison's extended sphere; the latter two have the motive and perhaps the means to mount protracted defenses of their interests. A third feature, consequent on the first two, is the duration of the defense. A single vote is short and republican, as is a holdout lasting a congressional term; resistance that survives several election cycles lies somewhere in the middle; and that which endures for decades is mixed-regime. ${ }^{14}$ Some subjectivity in these matters is unavoidable, and only at the extremes is the distinction fully clear.

The executive's veto offers an instructive illustration of the republican and mixed-regime understandings. An absolute veto befits a mixed regime when exercised by a hereditary monarch implementing a will independent of the majority. But an absolute veto is republican when exercised by an executive answerable to the people, and a qualified veto is doubly republican, since the legislative branches can combine to override it. On the other hand, even a qualified veto can have attributes proper to a mixed regime. Hugh Williamson, delegate from North Carolina, proposes a three-person executive to represent "three districts into which the States should be divided" (July 24, Farrand 1966-87, 2:100-101). The nation, as seen by Williamson, is an imperfect union made up of three regions-North, South, and Middle-each of which is to have its own president whom the people of the two other regions do not elect or reelect. Were one of the presidents within this executive to exercise a veto, he would be like a king to the people outside his region.

Besides the veto, the issue of executive number, whether single or plural, can itself be debated on republican and mixed-regime grounds. It is the former when independence in the executive is put against the risk of unsupervised power, for the aim is to strike a balance between effective government and responsible government; it is the latter when the executive is tasked with guarding the interests of a separate population within the society. ${ }^{15}$ Edmund Randolph of Virginia comes at the question from both angles, declaring a single executive "the foetus of monarchy" (June 1, Farrand 1966-87, 1:66) and, like

14. These three features are suggested by delegates' comments made in the course of the Convention (e.g., the insistence on institutional protections), but mainly they arise from reflection on the structure and operation of a mixed regime: the power to resist, the will to resist, and the evident fact of having resisted. The last of these is a check on what Madison derisively calls "parchment barriers" (Federalist 48). The time frames proposed are debatable and adjustable.

15. The purpose of republican precautions is to supply popular government with the competencies it lacks, namely, wisdom, stability, and justice, while yielding in the end to majority rule. Mixed-regime precautions may provide the same but at the expense of full popular sovereignty. 
Williamson, proposing that a plural executive have its presidents drawn from each of the country's three regions (June 2, 1:88). Randolph (partly) and Williamson (entirely) are analyzing the executive office using categories of a mixed regime.

The distinction between mixed regimes and republics also shows in the matter of popular elections. Some delegates-most notably Sherman, Randolph, and Elbridge Gerry of Massachusetts-discount the public's capacity for exercising the franchise. The people "want information and are constantly liable to be misled," says Sherman. Says Gerry, "The evils we experience flow from the excess of democracy." Echoing Gerry, Randolph adds that in tracing to their origin the evils under which the country labored, "every man had found it in the turbulence and follies of democracy" (May 31, Farrand 1966-87, $1: 48,51)$. Even George Mason of Virginia, who on the occasion argues vigorously for popular election of the lower house, equates the people's election of the chief magistrate to a color competition judged by blind men (July 17, $2: 31$ ). The verdict thus delivered by these delegates is that majority rule is undesirable (in some if not in all cases) because it is unwise, and the remedy proposed is not a minority veto but the exclusion of the people from direct involvement in the election of their rulers. The minority here is on the offensive, wanting to command the majority rather than slow it down by checking its power, and a constitution incorporating these features is mixed-regime, if not oligarchic/aristocratic. $^{16}$

The republican remedy for this wisdom deficiency attributed to the people is to enlarge the election districts in which the people cast their votes. James

16. It is possible to go too far in the direction of securing minority rights—or not far enough-and leave the arena of republic/mixed-regime competition altogether. A wider layout of regimes includes the alternatives and their consequences: democracy (unlimited majority rule resulting in majority tyranny), republic (unlimited majority rule tempered by republican precautions that guard against majority tyranny), mixed regime (limited majority/ minority rule checked by mixed-regime precautions that prevent majority/minority tyranny), oligarchy/aristocracy (unlimited minority rule resulting in minority tyranny), and monarchy (unlimited one-man rule resulting in one-man tyranny). This schema of regimes bears comparison with that offered by the Progressive historian James Allen Smith, who, being a Progressive, postulates historical progress: (1) "unlimited and irresponsible" government (i.e., absolute monarchy) in the beginning, succeeded by (2) "positively limited, negatively unlimited and irresponsible" government (i.e., mixed regime), culminating with (3) "unlimited and responsible" government (i.e., democracy) (Smith 1965, 128). Positive power initiates, negative power obstructs, and responsibility is to the people. Since the people are responsible to themselves only, majority tyranny is an illogical concept and an unfounded fear, and efforts to forestall it are rightly viewed (exposed) as a subterfuge disguising a conspiracy of the rich to impose minority rule. A republic, therefore, such as the American Constitution, is not so much a separate regime as an oligarchy effectively hidden, and indirect elections, terms of office, senatorial powers, the presidential veto, etc., are all clever devices by which the people are cheated of their right to rule. These are the presumptions that seemingly inspire the Progressive critique. 
Wilson of Pennsylvania is the chief advocate of extended-district voting, an idea closely related to, and sometimes confused with, Madison's extended sphere (Holton 2005). The purpose of the extended district is to free the voting public from the mischiefs and manipulations of local demagogues (June 6, Farrand 1966-87, 1:133; June 7, 1:154). Mistakes made by the public-such as a fondness for paper money-are not the product of any congenital and disqualifying defect. On the contrary, the public is wise enough and good enough for political participation so long as voting takes place inside large electoral districts. Because the large district is an auxiliary precaution that addresses a weakness of republican government (gullible voters) without abridging its egalitarian premise (popular election), the large district properly counts as a "republican remedy for the diseases most incident to republican government" (Federalist 10).

It is Madison's contention that auxiliary precautions of the republican variety provide adequate safeguards of minority liberty, since the extended sphere of a civilized society unbraces the majority by fracturing its cohesion. But some delegates, perhaps not comprehending or trusting in Madison's extendedrepublic theory, ${ }^{17}$ view auxiliary precautions as the main, if not only, line of defense-thus hardly as auxiliary at all. Accordingly, they want these precautions firmed up and made certain, even demanding that they be of the mixedregime variety. ${ }^{18}$

At the Convention there are three minority interests that receive the delegates' sustained attention and solicitude. They are small states, all states, and

17. As it happens, the Convention pays scant attention when Madison, on June 6, lays out the logic of the extended republic. New York delegate Robert Yates, in his Convention notes, makes only a passing reference to the theory, noting size as a factor in good order (Farrand 1966-87, 2:141), while his New York colleague, John Lansing, mentions Sherman's speech but not Madison's reply (4:56). Rufus King of Massachusetts confines himself to what appears to be the speech's opening subject, the election of quality representatives, or else he confuses the extended republic with the extended electoral district (2:143-44). William Pierce of Georgia offers a few sentences of desultory description, implying-if anything is implied - that Madison agrees with Sherman (i.e., a national government with few responsibilities) more than he disagrees (1:147). Hamilton does discuss the speech, briefly, under the heading "Madison's Theory," although Hamilton finds the theory wanting more than he finds it correct (1:146-47). And when Madison finishes, the next speaker, John Dickinson, simply returns to the topic of the day, the election of the lower house, proposing that it be kept with the people, while the election of the upper house be given to the state legislatures. Hutson $(1987,421)$ conjectures that the speech Madison delivered made little impression because it was not the impressive speech he subsequently wrote up and recorded. Kramer $(1999,637-39)$ attributes the Convention's neglect to the difficulty of digesting new ideas. Bad timing might be another, and simpler, explanation. See note 1 above.

18. It cannot be determined with absolute certainty that the delegates had mixed-regime models in mind as they crafted the Constitution. The claim that they did must rest on inference. It is inferred, for example, that delegates were thinking in mixed-regime terms when they used the British Constitution as an analog for the American one (see below for instances) - and even Madison compares the national negative to the king's veto over colo- 
southern states. ${ }^{19}$ The solution concerning the first is worked out entirely on the mixed-regime model. The solution concerning the second, when focused on the mode of electing the upper house, is mostly mixed-regime. For the third, the solution is partly mixed-regime and partly republican, although ideas are less consequential here than are interests.

Since the interests to be examined are in all cases states, it might be objected that the association they constitute is a federal republic and not a mixed regime. There are some observable differences between the two. First, a federal republic is ordinarily an association of whole communities each existing within its own well-defined geographical boundaries-an association more integrated than a confederation but less integrated than a consolidated union; a mixed regime, on the other hand, is ordinarily an association of social classes coexisting within a single community. Second, a federal republic (at least the one that emerges from the Convention) has limited, conferred powers and is additionally checked by its own internal organization, whereas a mixed regime has plenary power that is checked only by the need for agreement among the sover-

nial legislation ( July 17, Farrand 1966-87, 2:28). All delegates, having lived under the British Constitution, clearly knew of its representation of estates and of its division of powers. All would have been familiar with Montesquieu's analysis of that constitution as a mixed regime and with Montesquieu's endorsement of its liberty-protecting qualities. All came from states whose colonial charters were framed in imitation of Britain's mixed regime, even if they operated somewhat differently (Bailyn 1967, 59-105), and whose state constitutions, despite serious democratizing, were in some particulars still quasi-mixed-regime (Smith, 1965, 1226). For example, all state constitutions, excepting Pennsylvania's, imposed property qualifications on officeholders and limited suffrage usually to property-owning taxpayers (Hamilton, June 29, 1:465-66; Wakelyn 2006). The mixed regime, it seems fair to say, was part of the delegates' milieu, as common a currency as was republican theory ("the harmonizing sentiments of the day") when Jefferson wrote the Declaration (letter to Henry Lee, May 8, 1825; Jefferson 1944, 719). Of course, to argue that mixed-regime theory factored into the deliberations does not mean that it always presented itself in the form of high principle as opposed to low interest (see below).

19. Property constitutes a fourth minority interest and is the interest that most directly engages mixed-regime analysis. Hamilton, Morris, Mason, and many of the delegates from the Deep South all urge the representation of property. Hamilton ( June 18, Farrand 1966-87, 1:288-89) and Morris (July 2, 1:512-13) do so for explicitly mixed-regime reasons (separate social classes of rich and poor), while providing, along with Mason (June 26, 1:428), mixedregime devices for accomplishing the same: good-behavior terms (Hamilton and Morris), gratis service (Morris), and property qualifications (Mason). Even so, property is only sporadically addressed by Convention delegates, who in the end fail to devise any mechanism for representing wealth; rather, they persuade themselves that the representation of wealth can be accomplished by the representation of numbers (since in a manual-labor economy the number of hands laboring should roughly correspond to the amount of wealth produced; e.g., July $11,1: 579,585,588)$. The result is that the Constitution affords no formal recognition of property and provides no special means of protection; thus, wealth is left dependent on the extended sphere-and on the usual checks and balances of republicanism-to guard it from expropriation by the majority. 
eign parts (Smith 1965, 159). But these differences, rather than pointing to different constitutional creatures, may instead indicate that a federal republic is but a more effective form of mixed regime, the defining feature of which-the presence of a will independent of the majority-is equally defining of a federal republic. For the component parts of a federal republic are semisovereign governments ruling over separate, perhaps far-flung, territories; thus, the barrier they pose to national majorities is stronger and more persistently defended than is the barrier consisting of social class. In the standard mixed regime, by contrast, classes are conjoined in one government ruling over one, perhaps compact, space, wherein greater pressure can be exerted against the minority. ${ }^{20}$ Also, in a federal republic national majorities are limited to actions within a national jurisdiction vaguely marked out, whereas a prevailing majority in a mixed regime is jurisdictionally unbound. ${ }^{21}$

\section{MINORITY INTERESTS}

\section{SMALL STATES}

The small states with delegations present in Philadelphia during the relevant weeks of June and July are New Jersey, Delaware, and Maryland. They are supported by two not-so-small states, Connecticut and New York. The large states are Massachusetts, Pennsylvania, and Virginia. North Carolina, South Carolina, and Georgia, not yet large but expecting to be so soon, side generally with the large states.

The issue that divides states by size is representation in the legislature, particularly in the Senate. Small states want equal representation of states in accordance with past practices (the Continental Congress), current arrangements (the Constitutional Convention), and most confederal theory (e.g., June 30, Farrand 1966-87, 1:484). Large states want proportional representation of states in accordance with republican theory and the exigencies of union.

20. Madison observes that the British House of Lords, even though composed of hereditary nobles, "has not been able to defend itself against continual encroachments by the House of Representatives" (Federalist 63).

21. See Banning $(1987,162-87)$. Banning calls a federal republic a mixed regime $(165$, 173, 177). Despite proclaiming the Constitution "unmixed" in Federalist 14, Madison in Federalist 39 describes it as a mixture of national and federal elements. "National," it is here argued-and as Madison himself implies—corresponds to "republican" (a single, sovereign people exercising its will through majority rule, albeit tempered by the extended sphere and by auxiliary precautions), and "federal" corresponds to "mixed-regime" (separate communities with independent wills). Federalist 39, therefore, calls into question the argument of Federalist 51 (no wills independent of the majority) — as does this article. James Read detects a similar disconnect between Federalist 39 and Federalist 46 (Read 2000, 43-46). 
Madison takes the lead in explicating the superior justice of proportional representation and in warning against incorporation of an erroneous principle-equal representation-in the foundation of government (July 14, Farrand $1966-87,2: 8) .{ }^{22}$ Madison is given to viewing state-nation relations as an extension of county-state relations. In each case there is one corporate body that is junior to a second corporate body, its superior. In the latter case, the junior partners-counties-are never represented equally, irrespective of population and size; their voting power is rather proportionate to the number of their inhabitants and perhaps to their wealth. As an assurance that no harm will result from proportionality, Madison reminds the Convention that national legislators will come from and live in states, just as state legislators come from and live in counties, and that the ties that bind the latter will equally bind the former (June 21, 1:357).

Madison observes that the large states have no history of collusion and no conceivable incentive to combine against the small states. Massachusetts, Pennsylvania, and Virginia are separated geographically; they produce different staples for sale: fish, flour, and tobacco, respectively; and their people mostly differ in their Christian faiths: Puritan, Quaker, and Anglican, respectively. Large states are rivals more than they are allies, just as prominent individuals compete for honors more than they cooperate in common ventures, and independent states war against their equals more than they align to oppress the weak (June 28, Farrand 1966-87, 1:448-49). ${ }^{23}$

Suffice it to say, small-state advocates take a different view of their situation, since they remain unconvinced that no danger is presented by large-state cooperation. Oliver Ellsworth compares the small states to the British House

22. Previously, the core defect of confederations was said to be excessive power residing in the parts (June 19, Farrand 1966-87, 1:317; June 21, 1:356; also June 6, 1:137). Perhaps that point is not now repeated since it suggests that large states, posing a unique threat to the survival of the union, should be diminished in stature, by having their western lands taken from them and their congressional representation set at levels less than what their numbers would warrant.

23. These are but two of the many cogent arguments that Madison marshals in defense of proportional representation. The need to make them causes Madison to shift his ground from protecting the rights of minorities (the object of extended-republic theory) to establishing the majority's right to rule, and thus to align himself with the majoritarian James Wilson throughout much of the debates. If Madison seems less preoccupied with majority tyranny in his Convention speeches than in his pre- and post-Convention writings, the reason may be that small states are the minority most persistent in demanding special protections, and their fears of oppression Madison regards as baseless. Weiner (2012) calls Madison a majoritarian, but Weiner means by the label only that Madison recognizes no principle of legitimacy other than majority rule, not that Madison supposes majority rule to be wise and just and entitled to having its way immediately and without interference. See also Banning (1995, 127-29) and Sheehan (2009, 90-91). 
of Lords. He asks, "Is it a novel thing that the few should have a check on the many? . . . Have not the House of Lords, who form so small a proportion of the nation, a negative on the laws, as a necessary defence of their peculiar rights against the encroachment of the Commons" (June 30, Farrand 196687, 1:484). Ellsworth admits that evidence of collusion among the large states is lacking; nevertheless, he can imagine circumstances in which the little states suffer from an alliance of the big: a commercial treaty, for instance, creating a fixed number of free ports, could cause "Boston, Philadelphia, and some port in the Chesapeake" to bargain as one against their less influential neighbors, or the appointment of high officers could bring the big states together in an attempt to allocate positions among their favorite sons (June 30, 1:485; also June 29, 1:469; June 11, 1:196). Even Charles Pinckney, a nationalist and proportionalrepresentation proponent, is forced to concede that "the large States would feel a partiality for their own Citizens and give them a preference in appointments: that they might also find some common points in their commercial interests, and promote treaties favorable to them" (July 2, 1:510).

An earlier crack in the large-state alliance shows when Nathaniel Gorham of Massachusetts concedes that an equal number of representatives may not in all cases be equally effective. Madison cannot understand why Virginia, 16 times more populous than Delaware, should not have 16 times the representation (June 19, Farrand 1966-87, 1:321). Delaware will, and should, have the same legislative clout as Virginia when Delaware's representatives join with representatives of other states whose combined populations equal Virginia's. That way, equal numbers of people are represented by equal numbers of representatives. Fair is fair. But no, says Gorham, because Virginia's 16 representatives will more readily cooperate and vote as one than will 16 representatives drawn from three or four states (June 25, 1:404-5).

Sixteen Virginia representatives will exert more influence than any 16 representatives randomly combined, because Virginia imparts a common identity and purpose to its 16 , which the other 16 cannot match. Luther Martin of Maryland poses this question on the occasion of his two-day speech: "Will the representatives of a state forget state interests? .. . These prejudices cannot be eradicated-Your general government cannot be just or equal upon the Virginia plan, unless you abolish state interests" (June 28, Farrand 196687, 1:453). Even Alexander Hamilton of New York-perhaps the archest of all arch-nationalists—vouches for this small-state anxiety: "He admitted that common residence within the same State would produce a certain degree of attachment; and that this principle might have a certain influence in public affairs" (June 29, 1:466; also June 18, 1:285). Because identity, affection, and bonds of attachment will continue to root themselves in states, representatives will speak for their states, and Virginia, with representation proportionate to 
its population, will have a voice more commanding than Maryland's. Proportionality applies when all persons belong to the same community, a "perfect union"; then a majority of the whole can be said to speak for the whole. But when these persons are also, and perhaps first, citizens of their separate states, then proportionality augments the voice of a part that is speaking also, and perhaps first, for itself. Madison here is butting up against mixed-regime thinking and is making little headway as a result, failing even to keep his nationalist allies in line.

The decision to grant equal representation to states comes on July 16 . It stands as a clear instance of a mixed-regime precaution chosen over a republican one.

These designations, as noted, are often more relative than absolute, and so it remains to determine where on the spectrum of precautions equal representation falls. The way to proceed, as suggested, is by applying the three criteria given above: strength of barrier, cohesion of defenders, and duration of defense. The institutional barrier is a provision of the Constitution (Art. I.3), and a constitutional requirement is rated as among the strongest barriers of all. This particular barrier happens to be even stronger-is in fact adamant-because Article V of the Constitution (courtesy of Roger Sherman; September 15, Farrand 1966-87, 2:629) stipulates that "no State, without its consent, shall be deprived of its equal suffrage in the Senate." Cohesion of defenders hardly matters here, since defense itself is unnecessary, and duration of defense could hardly be longer, since equal suffrage is forevermore (Lee and Oppenheimer 1999). Nothing better reveals the mixed-regime proclivities of some Convention delegates than this exceptional provision, which is so mixed-regime as to defeat the very logic of a republican constitution.

\section{ALL STATES}

In addition to small states, the states themselves, all of them small republics in relation to the union and its national government, may be the object of discrimination too.

The support for states is almost universal at the Convention. Even those nationalists whose hopes lie with a consolidated union allow that the states have at least an administrative function to perform. Wilson goes further than this, separating himself from delegates who speak disparagingly of states and protesting his unwavering commitment to their survival (June 19, Farrand 1966$87,1: 322$; June $30,1: 484) .{ }^{24}$ The question, though, is how are the states to

24. One suspects, though, that Wilson protests too much, since he also calls states “imaginary beings" (June 30, Farrand 1966-87, 1:483). 
protect themselves and escape being absorbed by the union. The answer for some delegates is use of their legislatures as the electoral body of the upper house of Congress.

The election of the Senate, while not as controversial an issue as the representation of states within, still splits the delegates into nationalists and states' rights advocates. William Johnson of Connecticut explains precisely the conceptual problem that divides the Convention: some delegates, he supposes, consider "the States as districts of people composing one political society," while other delegates consider "them as so many political societies"-that is, semiautonomous communities. For the latter delegates, the states-if they are to exist- “must be armed with some power of self-defense.” Johnson's analog is the mixed regime in which the aristocratic element is invested with the institutional means of defending itself. Similarly "the States," he suggests, "have their interests as such, and are equally entitled to like means." The conclusion he draws, and the solution he recommends, is that "the two ideas embraced on different sides, instead of being opposed to each other, ought to be combined; that in one branch the people ought to be represented; in the other the States" (June 29, Farrand 1966-87, 1:461-62).

Johnson is not the first to come up with this idea. Its source is Roger Sherman (June 11), though in truth Sherman merely completes a suggestion originally offered by John Dickinson of Delaware. Ruminating on the disabilities of republican government-that it needs, but cannot accept, a strong executive, who perforce is a king-Dickinson, on June 2, looks for other remedies near at hand. One is bicameralism, seen as a check on legislative power. A second is the happy accident of division into states, important because a nobility gathered into a house of lords is lacking in America. A house of lords is a product of history, a "growth of ages" not to be conjured out of air, nor is it is an accommodation likely to be accepted by republics. But in Dickinson's estimation, the states can function as America's ersatz nobility, forming "the other principal source of stability." Accordingly, "considerable powers ought to be left with the States," for without them, "and in the case of a consolidation of the States into one great Republic," the fate of the country might be read "in the history of smaller ones" (June 2, Farrand 1966-87, 1:86-87). In other words, Madison's extended republic is but a small republic-and fated to produce a tyranny at the center-without the agency of the states.

Notwithstanding this characterization of the states as a quasi-nobility, Dickinson's thinking on the occasion is actually republican, not mixed-regime. Dickinson is the delegate who employs the water metaphor mentioned above. "If the State Governments," he argues, "were excluded from all agency in the national one ... the consequence would be that the national government 
would move in the same direction as the state governments now do, and would run into all the same mischiefs. The reform would only unite the 13 small streams into one great current pursuing the same course without any opposition whatever" (June 7, Farrand 1966-87, 1:153). As imagined by Dickinson, lawmaking by the national government, without check by the states, would result in a torrent of bad legislation. But this "one great current" can be tamed if the rush of water is first channeled into 13 streams. Channeling water to guard against erosion and flood is an auxiliary precaution becoming a republic, and Dickinson offers a republican justification for investing state legislatures with the power of electing the Senate, that is, to improve "the Councils of our Country." Johnson's justification, by contrast, is decidedly mixed-regime: “to preserve the individuality of the States" (June 21, 1:355).

The Johnson justification is the more commonly held view. Mason gives it 2 weeks earlier: "The State Legislatures also ought to have some means of defending themselves against encroachments of the National Government. In every other department we have studiously endeavored to provide for its selfdefense. Shall we leave the States unprovided with the means for this purpose?" (June 7, Farrand 1966-87, 1:155-56; also June 25, 1:407). Similar sentiments are expressed by Ellsworth (June 25, 1:406), Williamson (June 25, 1:407), and Pierce Butler of South Carolina (May 31, 1:51).

Madison is of a different mind. He wants nothing quite so much as a national government able to oversee the state governments through use of the negative, and he fears nothing quite so much as the state governments interfering with the business of the national government through election of any of its officials. He loses on both counts. ${ }^{25}$ The Virginia Plan's negative (already less than Madison's own $)^{26}$ survives until July 17 but is replaced in the end

25. Madison is disappointed on more occasions than just these two. According to Forrest McDonald's calculations, Madison loses on 40 proposals, motions, and seconds, while he wins on only 31 (McDonald 1985, 208-9). Cited by Banning (1995, 448n3), Robertson (2005, 232), and Weiner (2012, xi).

26. Madison urges a negative "in all cases whatsoever." See his pre-Convention letters to Thomas Jefferson (March 19, 1787), Edmund Randolph (April 8, 1787), and George Washington (April 16, 1787) (Madison 1975, 9:318, 370, 383-84, respectively), as well as his postConvention letter to Jefferson (October 24, 1787) (Madison 1977, 10:212-14). See also Hobson (1979, 215-35), Banning (1995, 117-19, 126-27), and Zuckert (1986, 87-99). Zuckert contends that Madison's universal negative was the institutional embodiment of the extended republic, the means by which the national government would intervene to prevent local majorities from oppressing local minorities. The national government, moderated by the extended sphere and utilizing the negative to overturn unjust state laws, would function like a monarch above the fray, impartially arbitrating disputes among society's quarreling factions; meanwhile, the state governments, still mainly responsible for securing rights and dispensing justice, would check the national government, converting use of its negative from the imperious decrees of an absolute monarch into the gentle persuasions of a limited mon- 
by the supremacy clause and judicial review (Schultz 1980, 221-22). ${ }^{27}$ And the Virginia Plan's election of the upper house by the lower house becomes on June 7 election of the upper house by state legislatures.

Madison and the nationalists lose these fights over the negative and the election of the Senate (also suffrage within the Senate) because mixed-regime arguments have saliency for the delegates. Minorities that present as distinct communities must have defensive powers outside the permissible boundaries of republican theory, whose core principle is the sovereignty of the people. That is so because republican precautions are unreliable and because the extended sphere cannot be expected to work its ameliorative magic in all cases whatsoever, and even Madison gives examples of where size and civilization fall short of expectations: (1) Rome, Athens, and Carthage and their respective provinces; (2) Great Britain and its American colonies; and (3) slavery based on color. Madison even allows that the indigent of America may one day constitute a solid, aggrieved, and envious mass, neutralizing the fragmenting effects of the extended sphere; then, adopting a "leveling spirit" and empowered by "the equal laws of suffrage," they may, as the majority, simply expropriate the property of others. He queries, "How is this danger to be guarded against on republican principles? How is the danger in all cases of interested coalitions to oppress the minority to be guarded against? Among other means by the establishment of a body in the Government [the Senate], sufficiently respectable for its wisdom and virtue, to aid on such emergencies the preponderance of justice by throwing its weight into that scale" (June 26, Farrand 1966-87, 1:422-23). The Senate here described is an auxiliary precaution, ${ }^{28}$ and the "other means" mentioned refer to other auxiliary precau-

arch. Zuckert's thesis connects with the thesis of this article in the following way: When Convention delegates ignore Madison's extended-republic theory, they let pass as well the limited-monarch/neutral-umpire option for preventing majority tyranny; they choose instead to invest the states-viewed as minorities in relation to the national government, itself viewed as the majority most likely to oppress-with the defensive powers to protect themselves, or with the precautions proper to a mixed regime. Other minorities-the actual objects of Madison's solicitude-they leave to the ministrations of the extended sphere or to the federal courts exercising judicial review. See Carey (1995, 47-50), who conditions the neutral-umpire option on the jury-like passivity of the national government, whose "low-key" impartiality is lost should activism become its mission. See also Robertson (2003, 194-205), Gibson (2008a), and Sheehan (2009, 92n26).

27. The power of judicial review, though not conferred by the Constitution, is anticipated by several of the delegates: Gerry (June 4, Farrand 1966-87, 1:97-98; July 21, 2:75), Martin (July 21, 2:76), Mason (July 21, 2:78), and Madison (July 23, 2:93; August 27, 2:430; September 12, 2:589). It is objected to by two of the delegates: John Francis Mercer of Maryland (August 15, 2:298) and Dickinson (August 15, 2:299).

28. In Federalist 63 Madison pointedly identifies the Senate as an "auxiliary precaution" supplementing the extended sphere. At the Convention he calls the council of revision an “auxiliary precaution" (July 21, Farrand 1966-87, 2:77). 
tions, since they cannot refer to the extended sphere, which, if it worked as advertised, would have prevented this indigent majority from forming in the first place or at least have softened its menacing aspect. And given that the efficaciousness of the Senate depends on the virtue and wisdom of its members, one can understand why some Convention delegates prefer the more steadfast precautions of a mixed regime to the more pliant ones of a republic.

Where, then, on the sliding scale of republican/mixed-regime precautions does election by state legislatures more precisely locate? The institutional barrier is state government, the strongest of all barriers-so very mixed-regime indeed. The cohesion of defenders, however, is not a given, since direct defenders are the senators elected, not the state governments electing them, and as the senators of each state are two in number, rather than just one, and vote per capita, rather than together, the vote of one senator might sometimes cancel out the vote of the other. ${ }^{29}$ Furthermore, the allegiance of senators may come into question, causing a mixed-regime precaution to drift over time in a republican direction. Such a drift is anticipated by Charles Cotesworth Pinckney of South Carolina, who worries that an esprit de corps will develop among national legislators, turning them into "federal" men (June 21, Farrand 1966-87, 1:365, 409; June 26, 1:421). His concern, which Sherman shares (June 21, 1:362, 365), is that assimilation, today called "Potomac fever," will wipe state loyalties clean away. And the emergence of national parties, beginning almost immediately, has caused senators ever since to vote more as party members than as representatives of their particular states, seen as "so many political societies," in the words of Samuel Johnson. The duration of defense, the third criterion, is fully mixed-regime, lasting until the early twentieth century when the Seventeenth Amendment moved election of senators from state legislatures to the voting public (Hoebeke 1995).

\section{SOUTHERN STATES}

The southern states are Maryland, Virginia, North Carolina, South Carolina, and Georgia. As a region they have three interests: the preservation of slave labor, the prohibition of export taxes levied on cash crops, and the protection

29. Luther Martin objects to the enlargement, noting that per-capita voting by two senators departs "from the ideas of the States being represented in the second branch" (July 23, Farrand 1966-87, 2:94). The doubling of senators is likely an example of pushback by the nationalists. Another is the absence of rotation and recall of lower-house legislators, provided for in the Virginia Plan (resolution 4) but removed from the final Constitution. The article's thesis is that the Constitution incorporates some mixed-regime elements, which means that it includes plenty of countervailing republican/nationalist elements as well. 
of commerce from regulations advantageous to the shipping and manufacturing interests of the North.

Slavery is denounced by some northerners at the Convention, but abolition is not seriously attempted. Northern opposition concentrates instead on curtailing the slave trade and minimizing the representation of slaves. An import tax on slaves still arriving from Africa and the Caribbean is a minor, third objective, and making a census irregular and voluntary is a fourth.

Throughout these debates southern delegates see their region as outnumbered, beleaguered, and in need of constitutional protections from majorities in the North. The South Carolinians are the most determined to throw up obstacles to abolitionist intrusion, and rarely do they suppose that the extended sphere will hold the North at bay (Rakove 1996, 77-79). The Southand especially the Deep South-is a separate region of the country made distinct by its peculiar institution. It will align on assurances that it can maintain its identity and safeguard its interests. John Rutledge and Charles Cotesworth Pinckney, helped sometimes by their South Carolina colleagues Pierce Butler and Charles Pinckney, succeed in extracting a host of proslavery exceptions to majority rule: a slave-import tax limited at 10 dollars a head; a fugitive slave clause requiring the return of runaway slaves; representation of slaves set at a ratio of three-fifths of free inhabitants, coupled with direct taxation set at the same three-fifths ratio (but never expected to be laid); a periodic and mandatory census to adjust representation and taxes; and a 20-year prohibition on congressional interference with the slave trade. ${ }^{30}$ All of these provisions, except the return of fugitive slaves, receive the added protection of a 20 -year immunity from constitutional amendment. This last security is the work of Rutledge, who realizes the danger of giving "a power by which the articles relating to slaves might be altered by the States not interested in that property and prejudiced against it" (September 10, Farrand 1966-87, 2:559). His intransigence is mollified, however, by the Convention's guarantee that the sovereign will of the nation, for 20 years at least, will not attempt by amendment to override the independent will of the South.

Where is Madison in relation to all of this special pleading? Not as opposed as one might think, and not as persistent in selling his extended-sphere palliative as one might expect. With elements of the Convention seemingly determined to utilize the Senate as a representative body of small-state interests, Madison submits that the real division in the country is North versus South, or free versus slave, and that a compromise more sensible than the represen-

30. Finkelman $(1987,190-92)$ provides an even fuller account of the Constitution's concessions to slavery. 
tation of large and small states in the lower and upper houses, respectively, is the representation of free persons in the former and of free and enslaved persons in the latter (June 30, Farrand 1966-87, 1:486-87; July 13, 1:601; July 14, 2:10). That way each region indirectly will have its own chamber by which to protect its own interests. But the use of bicameralism to represent permanent, regional interests hardly qualifies as an auxiliary precaution backstopping the extended sphere; rather, it is the creation of an independent will, or blocking power, granted to separate communities in a mixed regime. Madison confesses his reluctance to make the suggestion, concerned that it will highlight divisions "too apt to arise of [themselves]" and that it will distort the true nature of the Senate-that is, an assemblage of wise men exercising special powers (June 30, 1:487). ${ }^{31}$ Nevertheless, Madison proposes a system of regional representation in the Senate, even proposing that slaves be represented on a one-to-one basis with free whites (July 9, 1:562).

Madison does separate himself from the southern position when the issues are export taxes and the regulation of trade. The South exports tobacco, rice, and indigo. Combined, these crops constitute the largest portion of the country's annual exports. They make a tempting target for revenue extraction, and many delegates press the point that import taxes will not alone carry the burden of financing the government. Madison is willing to take a national view, since this power reserved to the states led to trade wars in the past. He tries to appease his fellow southerners with hopeful predictions about how export taxes will actually be paid by consumers at the other end and how exports will match imports in every state (since states must sell in order to buy) and so fall evenly on all, and he ventures the opinion that the South should pay more for requiring more government expense in the form of naval protection (August 16, Farrand 1966-87, 2:306-7; August 21, 2:361). But the argument is cut short because the export exclusion becomes part of a grand, North-South bargain over slavery and commerce on the one hand and taxation and representation on the other. ${ }^{32}$ The bargain is initially negotiated in the Committee of Detail (Art. VII.3-6), and the export provision, defended by Sherman and Ellsworth of Connecticut, easily survives debate in the Con-

31. According to Rakove (1987, 448-54), the North-South divide was a nut not to be cracked by Madison's extended-republic theory, since slave-based sectionalism was too obdurate an allegiance to succumb to the fragmenting effects of size and diversity. Zagarri (1987, 76-80) argues that Madison's attempt to redirect the debate toward slavery had the inadvertent effect of breaking apart the large-state coalition, insofar as some of its members now began to realize that proportionality was less important than regional solidarity. Madison quickly takes slavery off the table at the start of the Convention (May 30, Farrand 1966-87, 1:35-36). See also Beeman $(2009,107)$ and Broadwater $(2012,46,54)$.

32. See George Mason's speech at the Virginia ratifying convention (June 21, 1788), reprinted in Farrand (1966-87, 3:334-35). See also Collier and Collier (1986, 192-237) and Finkelman (1987, 209-23). 
vention (August 16, 2:307, 308; August 21, 2:359-60). Mason sees the matter in terms of regional protectionism: "He went on a principle often advanced and in which he concurred, that 'a majority when interested will oppress the minority.' . . . If we compare the States in this point of view the 8 Northern States have an interest different from the five Southern States. . . The Southern States had therefore good ground for their suspicions" (August 21, 2:362-63). Mason sounds Madisonian when starting out-interested majorities are a danger to minorities-but he finishes sounding like a mixed-regime protectionist, for he puts his faith in a constitutional ban on export taxes, rather than trusting that the diversifying effects of the extended sphere will fragment and moderate majorities sufficient for the auxiliary precautions of republicanism to take over.

The supermajority is the preferred southern remedy in regard to the regulation of trade, the second of these commercial issues. Charles Pinckney recommends that a two-thirds majority be required for passage of navigation acts. His reason is that the country, as he surveys it, divides into five economic zones, and the mere fact of difference ensures that some combination of interests will oppress the interests of the remainder. Madison's answer is that the Constitution's auxiliary precautions provide partial protection from abuse, namely, the bicameral legislature, the independence of the Senate, and the executive's veto, but that a first line of protection is afforded by the country's diversity. For two northern states, Connecticut and New Jersey, are agricultural, not commercial, while other northern states contain agricultural interests in their interiors, and western states, removed from the sea, are entirely agricultural. Out of this medley of interests, no fixed, commercial majority will form able to ride roughshod over a fixed, agricultural minority. Here Madison's plan of fragmenting majorities replaces the mixed-regime plan of fortifying minorities with extra-democratic powers. The South agrees to submit its economic interests to the determinations of majoritarian politics, confident that the country's size, supplemented by the auxiliary precautions of a republic, will suffice to prevent majority tyranny. Moreover, a delegate not ordinarily disposed to follow Madison's lead, Roger Sherman, references the theory of the extended sphere in explanation of his support, noting that "the diversity of interests was of itself a security." At last Madison has a convert!

But Sherman, of course, can afford to take this chance, since his state belongs to the northern majority positioned to oppress. It also is unlikely that argument alone-or even mainly-is responsible for preventing recourse to mixed-regime protections. For the decision regarding navigation acts, that they be subject to majority voting, turns out to be part of the larger NorthSouth bargain. Charles Cotesworth Pinckney, a hardliner on slavery, explains that while "it was the true interest of the Southern States to have no regulation of commerce ... he thought it proper that no fetters should be imposed on 
the power of making commercial regulations." The reasons he gives (with affected sympathy) are that the eastern states suffered losses to their commerce during the Revolution and (more honestly) "the liberal conduct toward the views of South Carolina" shown by their Convention delegates (i.e., Sherman and Ellsworth). Butler repeats the sentiment, attributing his vote against the two-thirds requirement to a desire to conciliate "the affections of the Eastern States." Finally, Rutledge offers the insouciant reassurance that "it did not follow from a grant of the power to regulate trade, that it would be abused." But to a southerner not party to the deal, such as Mason of Virginia, the power and its abuse are practically one and the same: "The Majority will be governed by their interests. The Southern States are the minority in both Houses. Is it to be expected that they will deliver themselves bound hand and foot to the Eastern States . . . ?" In case there is any doubt as to the source of this intersectional bonhomie, Madison, in a note, explains that "an understanding on the two subjects of navigation and slavery had taken place between those parts of the Union." When bare-knuckles bargaining is at work producing a "bundle of compromises," ideas are not likely to have much purchase. And if, on this occasion, ideas have any purchase at all, the idea of free markets proves just as alluring as the idea of extended spheres. For two North Carolinians, Williamson and Richard Spaight, take comfort in the thought that "if a majority of Northern States should push their regulations too far [respecting use of American bottoms], the Southern states would build ships for themselves" (August 29, Farrand 1966-87, 2:449-52).

To what degree, then, do the southerners succeed in creating a mixed regime around the issues of slavery and commerce? The Constitution affords protection to the continued practice of slavery (e.g., a head-tax cap, fugitive slave recapture) but not to the institution itself. Defense of slavery depends ultimately on the congressional delegations supporting it, but then the threefifths-representation provision augments southern voting power in the lower house, while the equal-suffrage provision augments it in the upper housesupposing that southern immigration outpaces northern and that the admission of new slave states outpaces the admission of new free ones (as is expected; July 11, Farrand 1966-87, 1:586; July 13, 1:605; July 25, 2:111; August 16, 2:305). Such advantages are mixed-regime. The defenders of slavery, however, must remain firm in their convictions, and the southerners at the Convention are not quite that (July 12, 1:594; August 22, 2:370, 372; August 25, 2:417). But opinion hardened a few decades later, mostly in response to abolitionist denunciations. Accordingly, the cohesion of defenders is, or in time became, mixed-regime. And the duration of the defense was likewise mixed-regime, ending after three-quarters of a century and only by means of war. 
In matters of commerce, the South wrings from the Convention a constitutional ban on export taxes, which is still in place ${ }^{33}$ - thus a mixed-regime precaution in two respects: the strength of the institutional barrier and the duration of the defense. (The cohesion of defenders is not an issue since the South was not attacked along this front.) Navigation acts, the other form of commerce, encounter no mixed-regime obstacles blocking their passage; rather, they are the product of majority rule, subject only to the republican precautions that generally apply (e.g., bicameralism) - a concession the South came to rue when northern-western majorities in the national legislature began passing tariffs. ${ }^{34}$ Moreover, the commerce clause has proven the preferred means by which federal power is extended into the states. The verdict, therefore, is that the provisions respecting slavery and commerce are partly mixed-regime and partly republican.

\section{CONCLUSION}

This review of the Convention debates suggests that the country was a long way from the "more perfect union" envisioned in the Constitution's preamble. Many of the delegates, still thinking of the union as a confederation of sovereign states, were willing to move in the direction of perfected union only if they were guaranteed protections of their states' rights and interests. Was it wise of them to have held fast to this localist, small-republic view, producing a Constitution with numerous features becoming a mixed regime? $\mathrm{Na}$ tionalists at the Convention thought not, pointing to unfavorable experience under the Confederation and to the dangerous impracticality of enforcing law on whole communities, when taken as the objects of governance (May 30, Farrand 1966-87, 1:34; June 20, 1:339). Morris expressed this disquietude when arguing against the representation of states, since states, he predicted, would declare null and void those laws they disliked (July 5, 1:530). Something near to that began to happen within a decade of ratification. Within four decades defiance of national authority came close to full boil, before finally abating, and three decades after that the top blew off as the country plunged into civil war. There is, then, a price to be paid for allowing communities their separate identities and the wherewithal to defend them (Onuf 1988, 48, 52).

The other view, best articulated by Tocqueville, holds that the egalitarian ethos lures people into a state of impotent isolation, leaving them vulnerable

33. Two recent Supreme Court cases reaffirmed the ban: United States $v$. IBM, 517 U.S. 843 (1996), and United States v. United States Shoe Corps, 523 U.S. 360 (1998).

34. These are the tariffs of 1816,1824 , and 1828-the last called the Tariff of Abominations. 
to and dependent on the power of government. Tocqueville calls this hyperprivatization "individualism," and he identifies it as the greatest threat to liberty in a democratic age. His main remedies are those habits and beliefs that help people restore some semblance of community, by learning and practicing the art of association (Democracy in America 2.2.2-9, 2.4.6). He suggests, therefore, that the nationalist dream of a single people under a single law, shorn of local identities and special protections, is not without its dangers, too.

\section{REFERENCES}

Adair, Douglass. 1998. Fame and the Founding Fathers. Edited by Trevor Colburn. Indianapolis: Liberty Fund.

Adams, John. 1850-56. Works of John Adams. Vols. 4 and 5. Edited by C. F. Adams. Boston: Little, Brown.

Bailyn, Bernard. 1967. The Origins of American Politics. New York: Vintage Books.

Banning, Lance. 1987. "The Practicable Sphere of a Republic: James Madison, the Constitutional Convention, and the Emergence of Revolutionary Federalism." In Beyond Confederation: Origins of the Constitution and American National Identity, ed. Richard Beeman, Stephen Botein, and Edward Carter. Chapel Hill: University of North Carolina Press.

- 1995. The Sacred Fire of Liberty: James Madison and the Founding of the Federal Republic. Ithaca, NY: Cornell University Press.

Beard, Charles. 1913. An Economic Interpretation of the Constitution of the United States. New York: Free Press.

Beeman, Richard. 2009. Plain, Honest Men: The Making of the American Constitution. New York: Random House.

Blackstone, William. 1979. Commentaries on the Laws of England: A Facsimile of the First Edition of 1765-1769. Vol. 1. Chicago: University of Chicago Press.

Brant, Irving. 1950. James Madison: Father of the Constitution, 1787-1800. Indianapolis: Bobbs-Merrill.

Broadwater, Jeff. 2012. James Madison: A Son of Virginia and a Founder of the Nation. Chapel Hill: University of North Carolina Press.

Carey, George W. 1995. In Defense of the Constitution. Indianapolis: Liberty Fund.

Coby, J. Patrick. 1999. Machiavelli's Romans: Liberty and Greatness in the Discourses on Livy. Lanham, MD: Lexington Books.

Collier, Christopher, and James Collier. 1986. Decision in Philadelphia: The Constitutional Convention of 1787. New York: Ballantine Books.

Davis, S. Rufus. 1978. The Federal Principle: A Journey through Time in Quest of a Meaning. Berkeley: University of California Press.

Diamond, Ann Stuart. 1978. "The Zenith of Separation of Powers Theory: The Federal Convention of 1787." Publius 8 (3): 45-70.

Diamond, Martin. 1992. As Far as Republican Principles Will Admit: Essays by Martin Diamond. Edited by William Schambra. Washington, DC: AEI.

Diamond, Martin, Winston Mills Fisk, and Herbert Garfinkel. 1966. The Democratic Republic: An Introduction to American National Government. Chicago: Rand McNally. 
Eidelberg, Paul. 1968. The Philosophy of the American Constitution: A Reinterpretation of the Intentions of the Founding Fathers. New York: Free Press.

Farrand, Max. 1966-87. The Records of the Federal Convention of 1787. 4 vols. Rev. ed. New Haven, CT: Yale University Press.

Finkelman, Paul. 1987. "Slavery and the Constitutional Convention: Making a Covenant with Death." In Beyond Confederation: Origins of the Constitution and American National Identity, ed. Richard Beeman, Stephen Botein, and Edward Carter. Chapel Hill: University of North Carolina Press.

Gibson, Alan. 2008a. "Impartial and the Extended Republic: Towards a Comprehensive and Balanced Reading of the Tenth Federalist Paper." In James Madison, ed. Terence Ball. Hampshire, UK: Ashgate.

—. 2008b. "Inventing the Extended Republic: The Debate over the Role of Madison's Theory in the Creation of the Constitution." In James Madison: Philosopher, Founder, and Statesman, ed. John R. Vile, William D. Pederson, and Frank J. Williams. Athens: Ohio University Press.

Gwyn, W. B. 1965. The Meaning of the Separation of Powers: An Analysis of the Doctrine from Its Origin to the Adoption of the United States Constitution. The Hague: Martinus Nijhoff.

Hobson, Charles F. 1979. "The Negative on State Laws: James Madison, the Constitution, and the Crisis of Republican Government." William and Marv Ouarterly 36 (2): 215-35.

Hoebeke, C.H. 1995. The Road to Mass Democracy: Original Intent and the Seventeenth Amendment. New Brunswick: Transaction.

Holton, Woody. 2005. “'Divide et Impera': Federalist 10 in a Wider Sphere.” William and Marv Ouarterly 62 (2): 175-212.

Hutson, James H. 1987. "Riddles of the Federal Constitutional Convention.” William and Marv Ouarterly 44 (3): 411-23.

Jefferson, Thomas. 1944. The Life and Selected Writings of Thomas Jefferson. Edited by Adrienne Koch and William Peden. New York: Modern Library.

Kramer, Larry. 1999. “Madison's Audience.” Harvard Law Review 112 (3): 611-79.

Lee, Frances E., and Bruce I. Oppenheimer. 1999. Sizing Up the Senate: The Unequal Consequences of Equal Representation. Chicago: University of Chicago Press.

Madison, James. 1975. The Papers of James Madison. Vol. 9. Edited by Robert Rutland et al. Chicago: University of Chicago Press.

- 1977. The Papers of James Madison. Vol. 10. Edited by Robert Rutland et al. Chicago: University of Chicago Press.

Mansfield, Harvey C., Jr. 1991. America’s Constitutional Soul. Baltimore: Johns Hopkins University Press.

McDonald, Forrest. 1985. Novus Ordo Seclorum: The Intellectual Origins of the Constitution. Lawrence: University Press of Kansas.

Miller, William Lee. 1992. The Business of May Next: James Madison and the Founding. Charlottesville: University of Virginia Press.

Nelson, William E. 1987. "Reason and Compromise in the Establishment of the Federal Constitution, 1787-1801." William and Marv Ouarterlv 44 (3): 458-84.

Onuf, Peter S. 1988. "Constitutional Politics: States, Sections, and the National Interest." In Toward a More Perfect Union: Six Essays on the Constitution, ed. Neil L. York. Provo, UT: Brigham Young University. 
Rakove, Jack N. 1987. "The Great Compromise: Ideas, Interests, and the Politics of Constitution Making." William and Marv Ouarterly 44 (3): 424-57.

- 1996. Original Meanings: Politics and Ideas in the Making of the Constitution. New York: Knopf.

Read, James H. 2000. Power versus Liberty: Madison, Hamilton, Wilson, and Jefferson. Charlottesville: University of Virginia Press.

Robertson, David Brian. 2003. "Constituting a National Interest: Madison against the States' Autonomy." In James Madison: The Theory and Practice of Republican Government, ed. Samuel Kernell. Stanford, CA: Stanford University Press.

- 2005. "Madison's Opponents and Constitutional Design." American Political Science Review 99 (2): 225-43.

Rossiter, Clinton. 1966. 1787, The Grand Convention. New York: Norton.

Rush, Benjamin. 1947. Observations on the Government of Pennsylvania. In Selected Writings, ed. D. Runes. New York: Philosophical Library.

Schultz, Harold S. 1980. “James Madison: Father of the Constitution?” Quarterly Journal of the Library of Congress 37 (2): 221-22.

Sheehan, Colleen A. 2009. James Madison and the Spirit of Republican Self-Rule. Cambridge: Cambridge University Press.

Slonin, Shlomo. 2000. "Securing State's Interests at the 1787 Constitutional Convention: A Reassessment.” Studies in American Political Development 14 (Spring): 1-19.

Smith, J. Allen. 1965. The Spirit of American Government. Cambridge, MA: Harvard University Press.

Wakelyn, Jon J. 2006. America's Founding Charters. Westport, CT: Greenwood.

Weiner, Greg. 2012. Madison's Metronome: The Constitution, Majority Rule, and the Tempo of American Politics. Lawrence: University Press of Kansas.

Wills, Garry. 1981. Explaining America: The Federalist. Garden City, NY: Doubleday.

Wolfe, Christopher. 1977. "On Understanding the Constitutional Convention of 1787." Lournal of Politics 39 (1): 97-118.

Wood, Gordon. 1969. The Creation of the American Republic, 1776-1787. Chapel Hill: University of North Carolina Press.

Zagarri, Rosemarie. 1987. The Politics of Size: Representation in the United States, 1776-1850. Ithaca, NY: Cornell University Press.

Zuckert, Michael. 1986. "Federalism and the Founding: Toward a Reinterpretation of the Constitutional Convention." Review of Politics 48 (2): 166-210.

- 1987. "A System without Precedent: Federalism in the American Constitution." In The Framing and Ratification of the Constitution, ed. Leonard W. Levy and Dennis J. Mahoney. New York: Macmillan.

—. 2003. "The Political Science of James Madison." In History of American Political Thought, ed. Bryan-Paul Frost and Jeffrey Sikkenga. Lanham, MD: Lexington Books.

- 2013. "James Madison in The Federalist: Elucidating 'The Particular Structure of this Government.'” In A Companion to James Madison and James Monroe, ed. Stuart Leibiger. Chichester, UK: Wiley-Blackwell.

Zvesper, John. 1984. “The Madisonian Systems.” Western Political Ouarterly 37 (2): 236-56. 